\title{
Aquatic insect diversity in two temple ponds of Silchar, Assam, N.E. India and their conservation values
}

\author{
A. Dalal ${ }^{(1)}$, S. Gupta ${ }^{(1), \star}$ \\ Received August 1, 2014 \\ Revised October 23, 2014 \\ Accepted October 31, 2014
}

Key-words: Aquatic insects, diversity, pond, Silchar

\section{ABSTRACT}

A study was carried out on the diversity and density of aquatic insect community in the two urban temple ponds - Radhamadhav akhra pond and Mandir dighi pond of Silchar town, Assam, Northeast India. All total 22 taxa of aquatic insects were recorded, 13 taxa from Radhamadhav akhra pond and 18 taxa from Mandir dighi pond. 9 taxa were found common in both the ponds. In Radhamadhav akhra pond classical relationship of dissolved oxygen and free carbon dioxide was established with low dissolved oxygen and high free carbon dioxide concentration. Pearson correlation coefficient analysis showed that the number of taxon was highly correlated with the density of taxon in both the ponds. Canonical correspondence analysis revealed that for Radhamadhav akhra pond, eigen values were 0.784 for axis 1 and 0.630 for axis 2 while for Mandir dighi pond eigen values were 0.825 for axis 1 and 0.740 for axis 2. Taxonenvironment correlation showed that aquatic insect community and environmental variables were highly correlated in both the ponds. Shannon diversity index of Radhamadhav akhra pond was in the range of 1.5-1.7 and Mandir dighi pond was in the range of 1.9-2.0. According to the dominance status by Engelmann's Scale, only Rhagovelia sp. was found Eudominant in Radhamadhav akhra pond. No eudominant taxon was found in Mandir dighi pond.

\section{RÉSUMÉ}

Diversité des insectes aquatiques dans deux étangs des temples de Silchar, Assam, NE Inde et leurs valeurs de conservation

Mots-clés : insecte aquatique, diversité, étang, Silchar
Une étude a été réalisée sur la diversité et la densité de la communauté d'insectes aquatiques dans les étangs de deux temples urbains Radhamadhav akhra et Mandir Dighi de la ville Silchar, Assam, Inde du Nord. Un total de 22 taxons d'insectes aquatiques a été enregistré, 13 taxons dans l'étang Radhamadhav akhra et 18 taxons dans l'étang Mandir Dighi. 9 taxons ont été trouvés communs aux deux étangs. Dans l'étang Radhamadhav akhra la relation classique entre l'oxygène dissous et le dioxyde de carbone libre a été constatée avec une faible concentration d'oxygène dissous et une concentration élevée de dioxyde de carbone libre. L'analyse des coefficients de corrélation de Pearson a montré que le nombre de taxons est fortement corrélé avec la densité de taxons dans les deux étangs. L'analyse canonique des correspondances a révélé que pour l'étang Radhamadhav akhra, les valeurs propres étaient 0,784 pour l'axe 1 et 0,630 pour

(1) Department of Ecology and Environmental Science, Assam University, Silchar, Assam, 788011, India

* Corresponding author: susmita.au@gmail.com 
l'axe 2 tandis que pour l'étang Mandir Dighi les valeurs propres étaient de 0,825 pour l'axe 1 et 0,740 pour l'axe 2 . La corrélation taxon-environnement a montré que la communauté d'insectes aquatiques et les variables environnementales étaient fortement corrélées dans les deux étangs. L'indice de diversité de Shannon de l'étang Radhamadhav akhra était de l'ordre de 1,5 à 1,7 et de l'ordre de 1,9-2,0 dans l'étang Mandir Dighi. Selon le statut de dominance de l'échelle d'Engelmann, seulement Rhagovelia sp. a été trouvé eudominant dans l'étang Radhamadhav akhra. Aucun taxon eudominant n'a été trouvé dans l'étang Mandir Dighi.

\section{INTRODUCTION}

Water is treated as a service provided by ecosystems. Together with energy and nutrients, water is arguably the centerpiece for the delivery of eco-system services to humankind (Falkenmark and Folke, 2003). The Millennium Ecosystem Assessment defines ecosystems as a dynamic complex of plant, animal and microorganism communities and their nonliving environment interacting as a functional unit. Despite their importance, freshwater ecosystems are rapidly being modified or destroyed (Allan and Flecker, 1993; Green et al., 2002) and many species have consequently become endangered (Abellan et al., 2005; Duncan and Lockwood, 2001; Perez-Losada et al., 2002). The global freshwater biodiversity crisis is most striking in tropical Asia (Dudgeon, 2003). Among different fresh water ecosystems the ponds, reservoirs and lakes of urban areas are highly affected. While urbanized area accounts only for $\sim 1$ to 6 percent of the earth surface, cities appropriate a large share of earth's carrying capacity in terms of resource input and waste sinks. By the year 2030, more than 60 percent (4.9 billion) of the estimated world population ( 8.1 billion) will live in cities: 56.2 percent of the population of developing countries (3.88 billion) and 83.5 percent of that of the developed countries (1.01 billion) (UN, 1999). The world's urban population will grow at an average annual rate of 1.8 percent, nearly double the rate expected for the total population of the world (1 percent per year). Since human being depends on earth ecosystems for food, water, and other important products and services, changes in ecological conditions that result from human actions in urban areas ultimately affect human health and well-being.

In urban areas fresh water systems have been misused for many centuries. Urban development fragments, isolates and degrades natural habitats; simplifies and homogenizes species composition; disrupts hydrological systems; and modifies energy flow and nutrient cycling (Alberti et al., 2003). Recent research, driven by the need to improve pond conservation strategies (Biggs et al., 2005; McAbendroth et al., 2005), has started to shed interesting new light on pond ecosystem structure and function. Despite their small size, they are collectively exceptionally rich in biodiversity terms (Williams et al., 2004).

Silchar (24. $49^{\prime} 47^{\prime \prime} \mathrm{N}$ Lat, $92^{\circ} 46^{\prime} 80^{\prime \prime} \mathrm{E}$ Long), a major city of south Assam and a district head quarter of Cachar, Assam, North east India is the principal commercial and health care centre for the people of the three districts of South Assam, entire state of Mizoram, and parts of Manipur and Tripura (Figure 1). According to the 2001 census the population of Silchar municipality area was $1,41,041$ with a decadal growth of $22.13 \%$. As such there is increasing trend of construction of multistoried building by draining and filling in the house hold ponds or community ponds of the municipality areas which have been serving the locality so long. At this juncture in this city, ponds or freshwater ecosystems of only sacred places which are very old and still vibrant with aquatic lives need to be conserved with utmost priority. The potential of community based land and resource management systems to conserve biodiversity begun to be recognized by anthropologists, biologists, conservationists, environmentalists, and others only in the last two decades. Hence the objectives of this study were to investigate and compare the aquatic insect diversity of two temple ponds, their water quality status and to find out the role of these ponds in biodiversity conservation. 


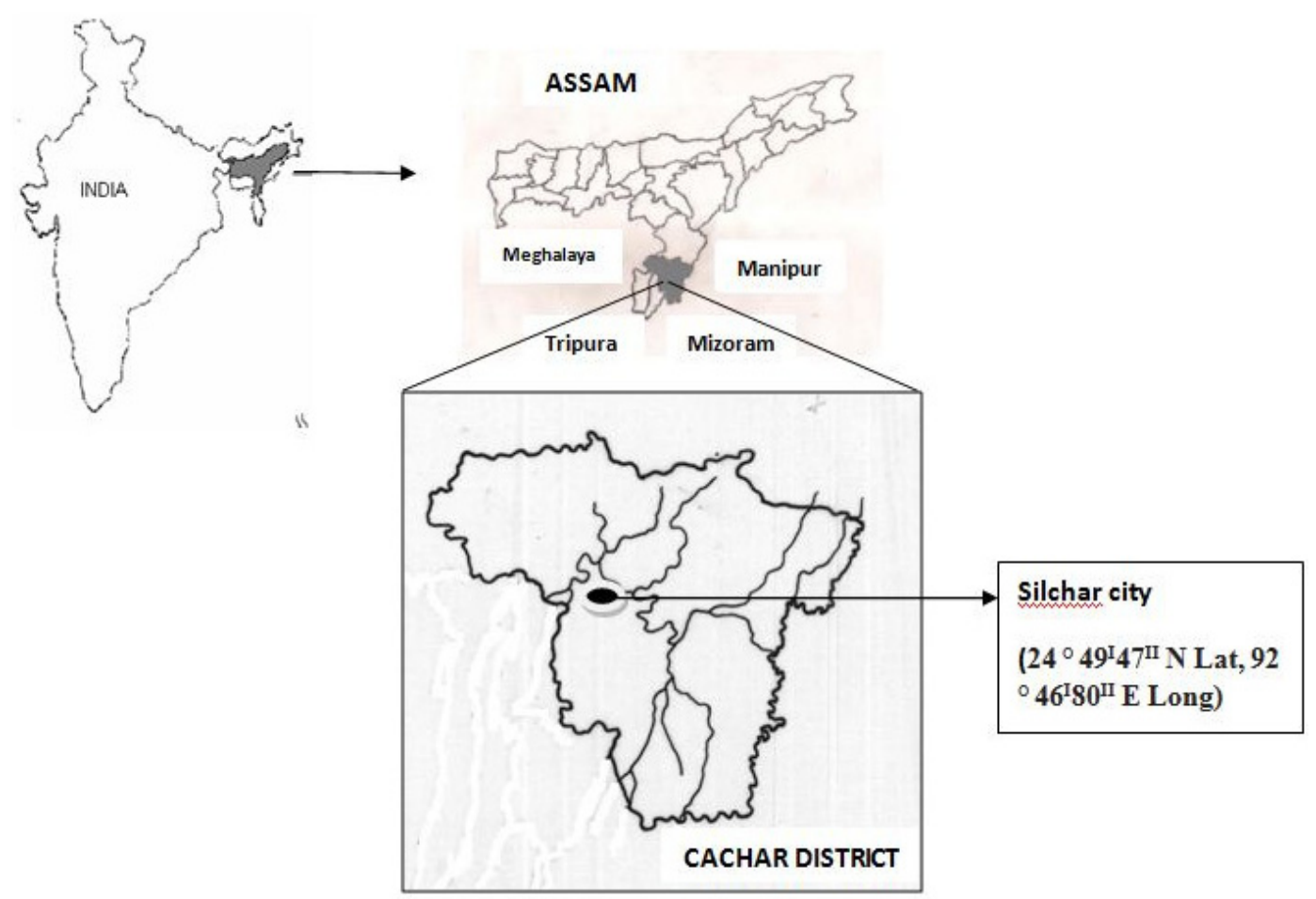

Figure 1

Map of Cachar district, Assam showing the Silchar city.

\section{MATERIALS AND METHODS}

The study was carried out for four months from February to May, 2012 in the two ponds, Radhamadhav akhra pond (pond 1) $\left(24^{\circ} 48^{\prime} 54.79^{\prime \prime} \mathrm{N}\right.$ and $\left.92^{\circ} 48^{\prime} 04.94^{\prime \prime} \mathrm{E}\right)$ and Mandir dighi pond (pond 2) $\left(24^{\circ} 49^{\prime} 07.06^{\prime \prime} \mathrm{N}\right.$ and $\left.92^{\circ} 48^{\prime} 02.86^{\prime \prime} \mathrm{E}\right)$ which are around 100 years old. Pond 1 is smaller in size (930 sq.m) located inside the temple compound and is covered with Lemna $\mathrm{sp}$. and Alternanthera philoxeroides while pond $2(12590.56 \mathrm{sq} \cdot \mathrm{m})$ is located in one residential area where one temple is located at the middle of the pond. Macrophytes recorded in this pond were Hydrocharis morsus ranae, Ipomea aquatica, Ceratophyllum demersum, Alternanthera philoxeroides, Cynodon dactylon, Colocasia esculenta, and Eichhornia crassipes.

Water and insect samples were collected fortnightly in three replicates during 29th February to 1 st May, 2012 from site 1 and site 2 of pond 1 and site 3 , site 4, and site 5 of pond 2 . There were five visits during the study period. Air and water temperature (AT and WT) were measured using mercury bulb thermometer while transparency (TR) was measured using Secchi's disk. Physico-chemical properties of water such as dissolved oxygen (DO), free carbondioxide $\left(\mathrm{FCO}_{2}\right)$ total alkalinity $(\mathrm{TA}), \mathrm{pH}$, electrical conductivity $(\mathrm{EC})$, nitrate $\left(\mathrm{NO}_{3}^{-}\right)$, phosphate $\left(\mathrm{PO}_{4}^{3-}\right)$ were analyzed by standard methods (APHA, 2005; Michael, 1984). Aquatic insects were collected by kick method whereby the vegetation was disturbed and a circular net (mesh size $60 \mu \mathrm{m}$ ) was dragged around the vegetation for a unit of time (Brittain, 1974; Macan and Maudsley, 1968). Three such drags constituted a sample (Subramanian and Sivaramakrishnan, 2007). Collected insects were immediately sorted and preserved in $70 \%$ ethyl alcohol. They were later identified using a Dewinter advanced stereozoom microscope with the help of standard keys (Bal and Basu, 1994a, 1994b; Bouchard, 2004; Epler, 2010; Kumar, 1973a, 1973b; Westfall and Tennessen, 1996). Diversity indices were worked out using the package PAST. For statistical analysis SPSS v.20 was used. CCA (Canonical correspondence analysis) was performed using CANOCO v. 4.5. SIGNAL (Stream Invertebrtae Grade Number-Average Level) was analyzed following the literature of Chessman (2003). 


\section{RESULTS AND DISCUSSION}

Urban ecosystems are highly dynamic and have usually been examined in terms of their impact on biodiversity (Adams, 1994; Gilbert, 1989; Middleton, 1994; Wackernagel and Rees, 1996). The physico-chemical characteristics of any aquatic ecosystem and the nature and distribution of its biota are directly related to and influenced by each other and controlled by a multiplicity of natural regulatory mechanisms (Bhat et al., 2009). Thus macro-invertebrates have served as valuable indicators of degradation of aquatic ecosystems. According to Wallace and Webster (1996) as there is increasing pressure on our water resources, macroinvertebrates should be used for assessing the impact of pollution in aquatic ecosystems. They cannot change their habitats quickly because of their less moving ability and they respond to any pollutants by changing their community composition (Turkmen and Kazanci, 2010).

\section{> PHYSICO-CHEMICAL VARIABLES}

The physico-chemical variables of water of the two ponds did not show much fluctuation except DO concentration. The most striking feature of water of pond 1 is low DO $\left(2.08 \mathrm{mg} \cdot \mathrm{I}^{-1}\right.$ in site 1 and $1.94 \mathrm{mg} \cdot \mathrm{I}^{-1}$ in site 2$)$ while in pond $2 \mathrm{DO}$ is relatively high $\left(6.82 \mathrm{mg} \cdot \mathrm{I}^{-1}\right.$ in site 3 , $7.83 \mathrm{mg} \cdot \mathrm{I}^{-1}$ in site 4 and $7.13 \mathrm{mg} \cdot \mathrm{I}^{-1}$ in site 5) (Table I). In both the ponds $\mathrm{pH}$ showed highly significant positive relationship with TR. In the pond 1 both diversity and density of insect taxa showed highly significant positive correlation with TR and significant negative relationship with TA. The pond is covered by Lemna sp. which obstructs penetration of light facilitating more amount of organic matter decomposition instead of photosynthesis. This is confirmed by very low $\mathrm{DO}$, higher concentration of $\mathrm{FCO}_{2}$ compared to pond 2 and absence of its significant relationship with free $\mathrm{CO}_{2}$ (Table I). In pond $2 \mathrm{FCO}_{2}$ showed significant negative relationship with TR, $\mathrm{pH}$ and DO. Significant classical negative correlation of DO with $\mathrm{FCO}_{2}$ showed that photosynthesis was the main driver of DO production in the system. Significant positive correlation between $\mathrm{DO}$ and $\mathrm{PO}_{4}^{3-}$ could be due to the fact that high sunlight penetration and $\mathrm{PO}_{4}^{3-}$ concentration increased phytoplankton in the pond which in turn produced more DO. The significant positive relationship of $\mathrm{pH}$ with $\mathrm{PO}_{4}^{3-}$ is due to the fact that at high $\mathrm{pH}$, phosphorus is released from sediment during summer (Brabrand et al., 1990) (Table II).

\section{$>$ AQUATIC INSECTS}

In both pond 1 and 2, insect density showed very high significance with the taxa richness (Table II). A total of thirteen taxa from pond 1 and eighteen taxa from pond 2 were recorded. The study revealed that though the density of insect was found highest in pond 1 (1st visit, site 2), the number of insect taxon was found highest in pond 2 (2nd visit, site 3) (Figure 2). In pond 1 four aquatic insect orders (Hemiptera, Odonata, Diptera and Coleoptera) and in pond 2 five orders (Hemiptera, Odonata, Diptera, Coleoptera, and Ephemeroptera) were recorded. Preponderance of order Hemiptera with very low DO in pond 1 could be explained by the fact that aquatic and semiaquatic Hemipterans do not rely heavily on DO in the water due to their abilities to utilize atmospheric oxygen, by possessing respiratory apparatus (siphon, plastron, presence of hemoglobin etc.) (Fernando and Cheng 1974; Lansbury 1972; Thorpe and Crisp 1947; Thorpe 1950; Wells et al., 1981). In the lakes and rivers of North East India also preponderance of Hemiptera has been noted in several studies (Das and Gupta 2010; Gupta and Narzary 2013; Purkayastha and Gupta 2012, 2013; Takhelmayum and Gupta 2011). The dominance status according to Engelmann's Scale (Engelmann, 1978) at pond 1 revealed Rhagovelia sp. as eudominant taxon while Mesovelia sp. and Mesovelia vittigera as dominant taxa. In contrast, at pond 2 no taxon was found eudominant (Table III). This is reflected in the high Shannon diversity index values in all sites of pond 2 indicating taxon richness and evenness. This is further confirmed by their low Berger Parker index of Dominance value (Table IV). 


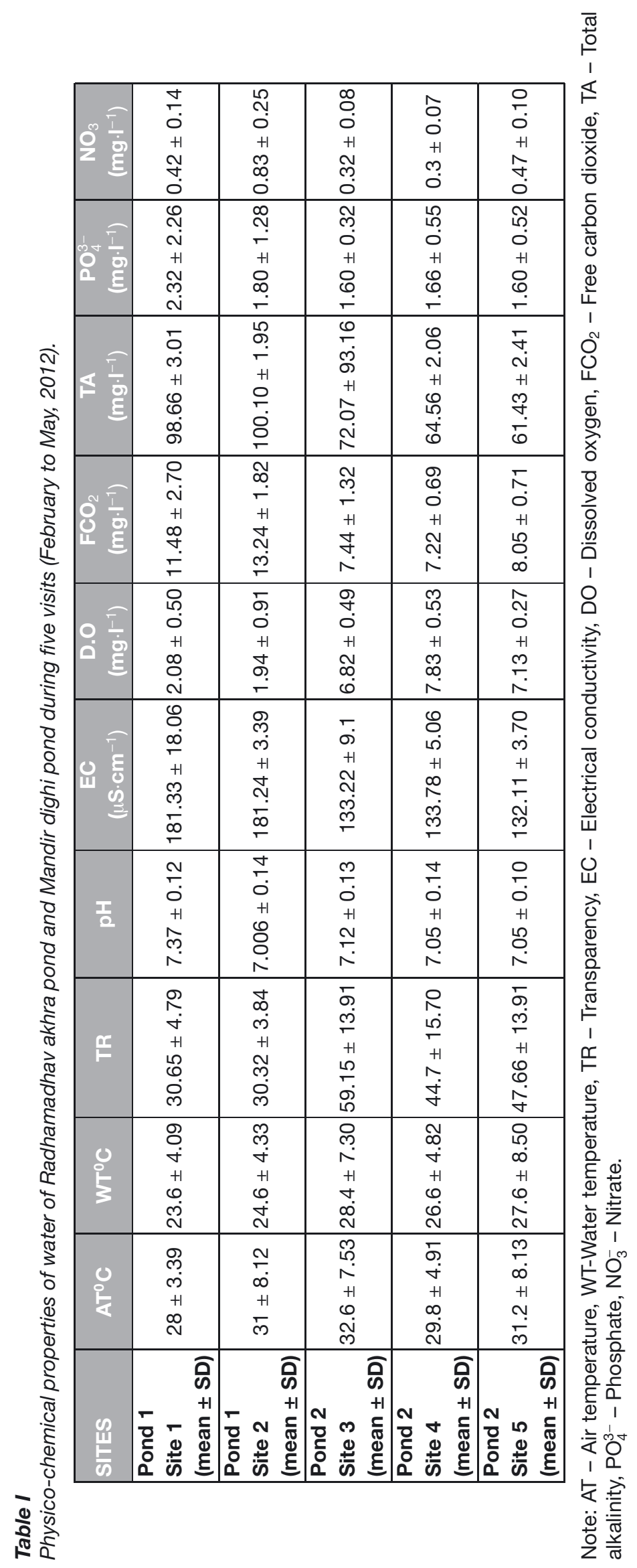




\section{Table II}

Significant correlations among different physico-chemical variables, aquatic insect diversity and density in Radhamadhav akhra pond and Mandir dighi pond.

\begin{tabular}{|c|c|c|}
\hline Variables & Pond 1 & Pond 2 \\
\hline AT vs. WT & $0.745\left(^{(* \star}\right)$ & $\left.0.857^{(\star \star}\right)$ \\
\hline TR vs. WT & $-0.707\left(^{\star \star}\right)$ & $0.344\left(^{*}\right)$ \\
\hline pH vs. WT & $-0.469\left(^{* \star}\right)$ & - \\
\hline pH vs. TR & $\left.0.483^{(* \star}\right)$ & $\left.0.691^{(\star \star}\right)$ \\
\hline TA vs. AT & $\left.0.534^{(* \star}\right)$ & $0.386\left(^{(\star}\right)$ \\
\hline TA vs. WT & $\left.0.670^{(* *}\right)$ & - \\
\hline TA vs. TR & $-0.805\left(^{(\star)}\right.$ & - \\
\hline NO3- vs. AT & $\left.0.531^{(* \star}\right)$ & $0.303\left(^{*}\right)$ \\
\hline NO3- vs. WT & $0.455\left(^{\star \star}\right)$ & $0.341\left(^{*}\right)$ \\
\hline NO3- vs. FCO2 & $\left.-0.5899^{(*}\right)$ & $-0.704\left(^{* *}\right)$ \\
\hline Density vs. TR & $0.522\left(^{(* *}\right)$ & - \\
\hline Density vs. taxon & $0.898\left(^{(*}\right)$ & $0.848\left(^{(\star}\right)$ \\
\hline FCO2 vs. AT & $-0.368\left(^{*}\right)$ & $-0.327\left(^{*}\right)$ \\
\hline FCO2 vs. WT & $-0.445\left(^{*}\right)$ & - \\
\hline Taxon vs. TR & $0.425\left(^{*}\right)$ & - \\
\hline Density vs. TA & $-0.422\left(^{*}\right)$ & - \\
\hline FCO2 vs. TR & - & $\left.-0.5322^{(\star \star}\right)$ \\
\hline FCO2 vs. pH & - & $-0.560\left(^{* \star}\right)$ \\
\hline FCO2 vs. EC & - & $-0.359\left(^{*}\right)$ \\
\hline FCO2 vs. DO & - & $-0.338\left(^{*}\right)$ \\
\hline PO43- vs. pH & - & $0.503\left(^{\star \star}\right)$ \\
\hline PO43- vs. DO & - & $0.496\left({ }^{* \star}\right)$ \\
\hline PO43- vs. TR & - & $0.362\left(^{*}\right)$ \\
\hline NO3- vs. EC & - & $0.341\left(^{*}\right)$ \\
\hline DO vs. pH & - & $0.362\left(^{*}\right)$ \\
\hline DO vs. EC & - & $-0.337\left(^{\star}\right)$ \\
\hline
\end{tabular}

** Correlation is significant at the 0.01 level (2-tailed).

* Correlation is significant at the 0.05 level (2-tailed).

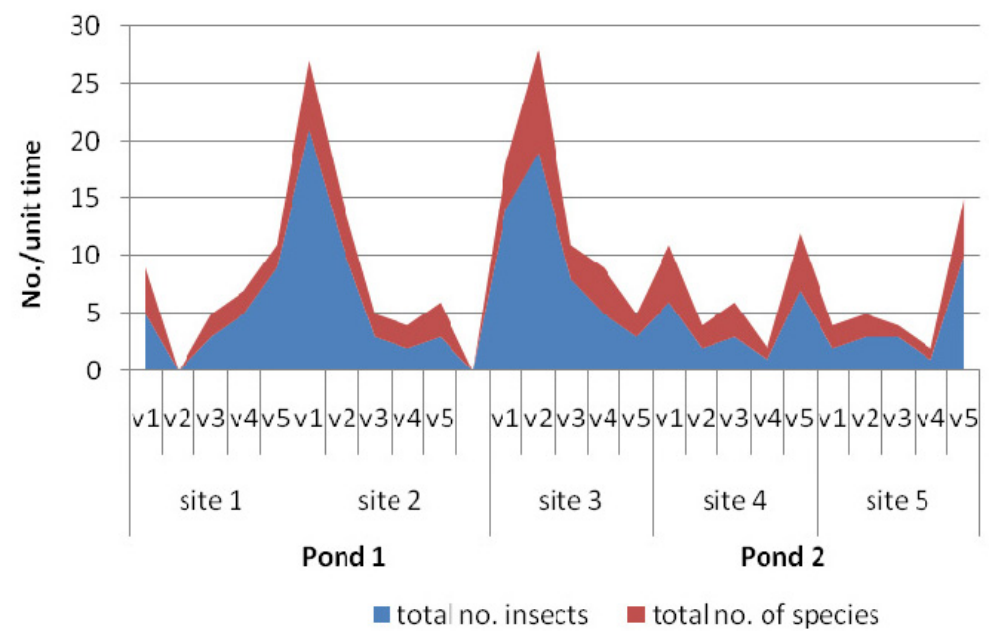

Figure 2

Density of insects and number of taxa at 5 different sites of Radhamadhav akhra pond and Mandir dighi pond during five visits (February to May, 2012) (v1, v2, v3, v4, v5 = Visits 1 to 5). 


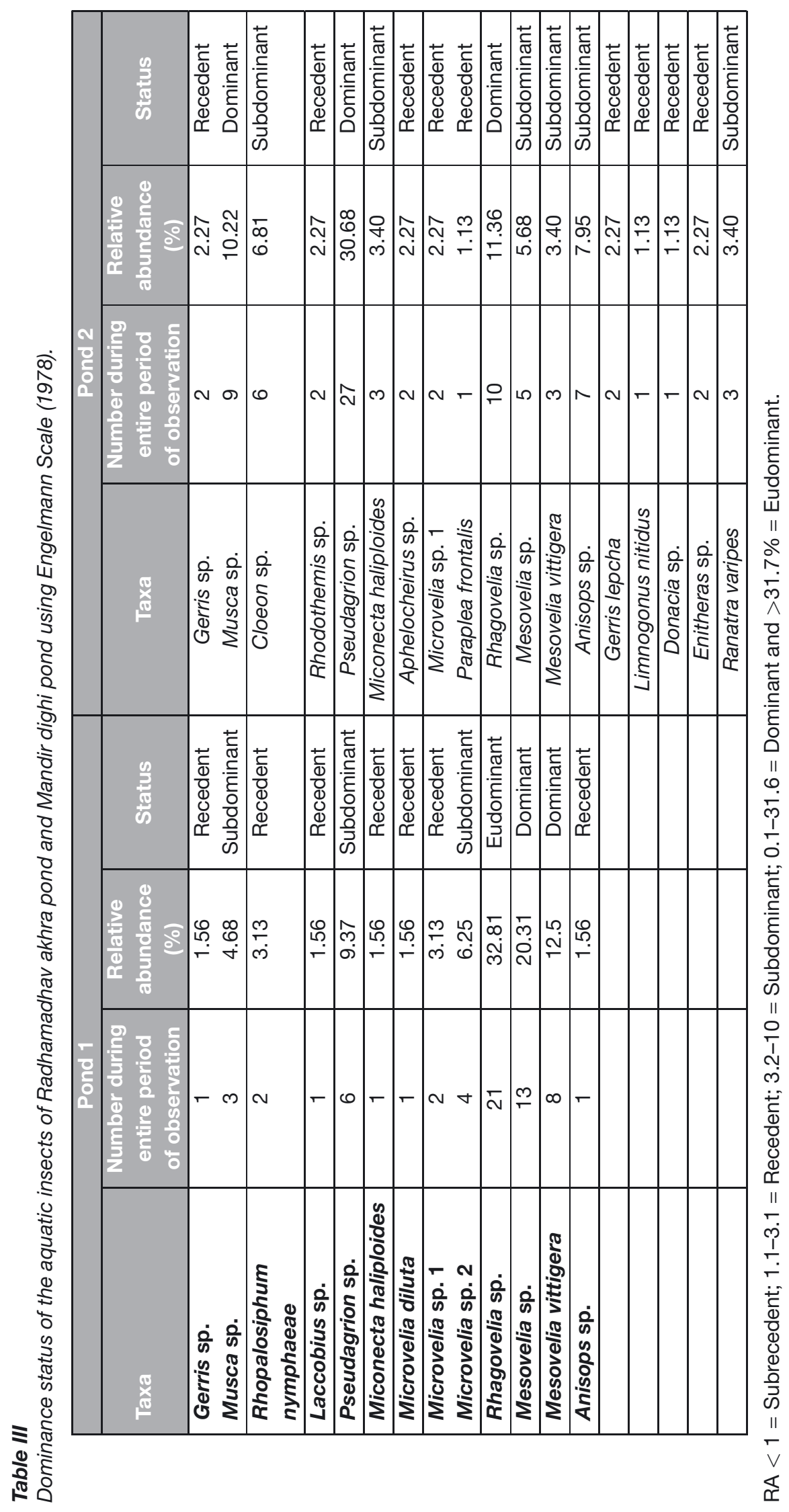




\section{Table IV}

Diversity indices of Radhamadhav akhra pond and Mandir dighi pond.

\begin{tabular}{|l|c|c|c|c|c|}
\cline { 2 - 6 } \multicolumn{1}{c|}{} & \multicolumn{2}{c|}{ Pond 1 } & \multicolumn{3}{c|}{ Pond 2 } \\
\hline Diversity indices & Site 1 & Site 2 & Site 3 & Site 4 & Site 5 \\
\hline Shannon_H & 1.553 & 1.789 & 2.014 & 1.928 & 2.078 \\
\hline Evenness_êH/S & 0.6753 & 0.5442 & 0.8324 & 0.8591 & 0.5708 \\
\hline Margalef & 1.941 & 2.675 & 2.717 & 2.377 & 3.323 \\
\hline Berger-Parker Index of Dominance & 0.5 & 0.4762 & 0.3158 & 0.2632 & 0.36 \\
\hline
\end{tabular}

Table $V$

Signal score for Radhamadhav akhra pond.

\begin{tabular}{|c|c|c|c|c|}
\hline Family & $\begin{array}{c}\text { SIGNAL } \\
\text { sensitivity grade }\end{array}$ & $\begin{array}{c}\text { No. } \\
\text { of specimen }\end{array}$ & $\begin{array}{l}\text { Weight } \\
\text { factor }\end{array}$ & $\begin{array}{c}\text { Grade* } \\
\text { Weight factor }\end{array}$ \\
\hline Gerridae & 4 & 1 & 1 & 4 \\
\hline Corixidae & 2 & 1 & 1 & 2 \\
\hline Veliidae & 3 & 28 & 5 & 15 \\
\hline Mesoveliidae & 2 & 21 & 5 & 10 \\
\hline Coenagrionidae & 2 & 6 & 3 & 6 \\
\hline Muscidae & 1 & 3 & 2 & 2 \\
\hline Hydrophilidae & 2 & 1 & 1 & 2 \\
\hline Notonectidae & 1 & 1 & 1 & 1 \\
\hline Total & & & 19 & 42 \\
\hline
\end{tabular}

N.B.: SIGNAL score $=$ Total of Grade ${ }^{*}$ weight factor/ Total of weight factor Signal Score $=42 / 19=2.21$.

The values of Shannon diversity index at both pond 1 (1.5 to 1.7) and pond 2 (1.9 to 2.0) were within proper range (1.5-3.5) (Turkmen and Kazanci, 2010). Evenness_êH/S values of pond $1(0.5-0.6)$ and pond $2(0.5-0.8)$ revealed that the values of pond 2 being closer to 1 indicated equal distribution of individuals. (Turkmen and Kazanci, 2010). This is confirmed by the lowest Berger Parker index of dominance at the site 5 of pond 2 . The ranges of Berger Parker index values for pond 1 and pond 2 were 0.4 to 0.5 and 0.2 to 0.3 , respectively. The values of Margalef diversity index were between 1.94-2.67 at pond 1 and 2.37-3.32 at pond 2. The highest value was found at site 3 of pond 2. According to Lenat et al. (1980) Margalef water quality index values (diversity indices of Margalef) greater than 3 indicate clean conditions, values less than 1 indicate severe pollution and intermediate value indicate moderate pollution. In the present study only in site 3 (pond 2) the Margalef Diversity Index value was found above 3 indicating clean condition whereas all other sites were found in the range of moderate pollution (Table IV).

SIGNAL (Stream Invertebrate Grade Number-Average Level) is the family level index of water pollution for the known tolerances of aquatic insect families to various pollutants. However, for lentic ecosystems the SIGNAL scores was lower as compared to stream ecosystem because of unavailability of the insects in lentic systems that are found in stream ecosystem (Chessman, 2003). SIGNAL score of pond 1 (2.21) was found lower than pond 2 (2.5) (Tables $V$ and $\mathrm{VI}$ ). SIGNAL score less than 4 indicate severe pollution. Therefore, according to SIGNAL score both the ponds were under severe pollution status (Gooderum and Tsyrlin, 2002).

At pond 2 record of Cloeon sp., family Baetidae, order Ephemeroptera is of importance. Although Ephemeroptera larvae are recognized worldwide for their sensitivity to oxygen depletion in running waters (Rosenburg and Resh, 1993), mayflies inhabiting lentic waters, like lakes and ponds, in contrary have been poorly prospected in biomonitoring (Menetrey et al., 2008). In Lake Erie, Ephemeroptera are successfully used in biomonitoring, following the example of a recent study that showed burrowing mayfly nymphs (Hexagenia sp.) to be associated with an improvement of the ecosystem health (Schloesser and Nalepa, 2002). In the present study although Cloeon sp. belonging to the family Baetidae was recorded in the sites 3 and 4 of 


\section{Table VI}

Signal score for Mandir dighi pond.

\begin{tabular}{|l|c|c|c|c|}
\hline Family & $\begin{array}{c}\text { SIGNAL } \\
\text { sensitivity grade }\end{array}$ & $\begin{array}{c}\text { No. } \\
\text { specimen }\end{array}$ & $\begin{array}{c}\text { Weight } \\
\text { factor }\end{array}$ & $\begin{array}{c}\text { Grade * } \\
\text { Weight factor }\end{array}$ \\
\hline Gerridae & 4 & 5 & 2 & 8 \\
\hline Pleidae & 2 & 1 & 1 & 2 \\
\hline Corixidae & 2 & 3 & 2 & 4 \\
\hline Veliidae & 3 & 12 & 4 & 12 \\
\hline Mesoveliidae & 2 & 8 & 3 & 6 \\
\hline Notonectidae & 1 & 9 & 3 & 3 \\
\hline Nepidae & 3 & 3 & 2 & 6 \\
\hline Libellulidae & 4 & 2 & 1 & 4 \\
\hline Coenagrionidae & 2 & 27 & 5 & 10 \\
\hline Baetidae & 5 & 6 & 3 & 15 \\
\hline Muscidae & 1 & 9 & 3 & 3 \\
\hline Chrysomelidae & 2 & 1 & 1 & 2 \\
\hline Total & & & 30 & 75 \\
\hline
\end{tabular}

N.B.: SIGNAL score $=$ Total of Grade ${ }^{\star}$ weight factor/ Total of weight factor.

Signal score $=75 / 30=2.5$.

pond 2 having high DO values, according to Margalef water quality index values only site 3 is in clean condition while rest were in moderate pollution range. Menetrey et al., (2007) in their study revealed that Cloeon sp. could be found in either mesotrophic or eutrophic habitats and family Baetidae appears as one of the Ephemeropteran families the most tolerant to organic pollution. This agreed with the findings of a study made in the oxbow lake (Phulbari anua) of Cachar district where preponderance of Cloeon sp. was recorded in moderately polluted condition (Gupta and Narzary, 2013). Brönmark and Hansson (2000) found that Caenidae and Baetidae families contain some of the most resistant species to organic pollution. Several workers (Braasch and Jacob, 1976; Garcia de Jalon and Gonzalez del Tanago, 1986; Hellawell, 1986; Hubbard and Peters, 1978, Janieva, 1979; Russev, 1979) throughout the world have published several results with respect to the tolerance degree of many species.

\section{> CANONICAL CORRESPONDENCE ANALYSIS (CCA)}

CCA ordination diagram of pond 1 and pond 2 depict the relationship between aquatic insect community and environment variables (Figures 3 and 4).

In pond 1 , the eigen values were 0.780 and 0.658 of axis 1 and 2, respectively. Similarly, for pond 2 the eigen values were 0.825 and 0.740 for axis 1 and 2 , respectively. Taxonenvironment correlation of the two axes were 0.956 and 0.947 for pond 1, and 0.958 and 0.935 for pond 2 which showed strong relationship of the aquatic insect community with the environment variables. Cumulative percent variance of taxa data for axis 1 and 2 were 18.4 and 33.9 respectively in pond 1 while in pond 2 it was 12 for axis 1 and 22.8 for axis 2 . Cumulative percent variance of taxa-environment relation for axis 1 and 2 were 25.4 and 46.7, respectively in pond 1 whereas 25.3 and 48 in axis 1 and 2, respectively in pond 2.

Monte Carlo test was performed with 499 unrestricted permutations and were found significant in both the ponds $(P<0.002$ : Tables VII and VIII).

The CCA ordination diagram (Figure 3 ) in pond 1 showed that both the environmental variables and the macro-invertebrate assemblages were homogeneously scattered. Rhagovelia $\mathrm{sp}$. was found positively correlated with nitrate. Gerris sp. was found positively correlated with TR. Mesovelia vittigera was positively correlated with EC while Microvelia diluta, Microvelia sp.1, sp.2 and Laccobius sp. were associated with the increased AT and WT. In pond 2, the CCA ordination diagram (Figure 4) revealed maximum macro- invertebrates assemblages 


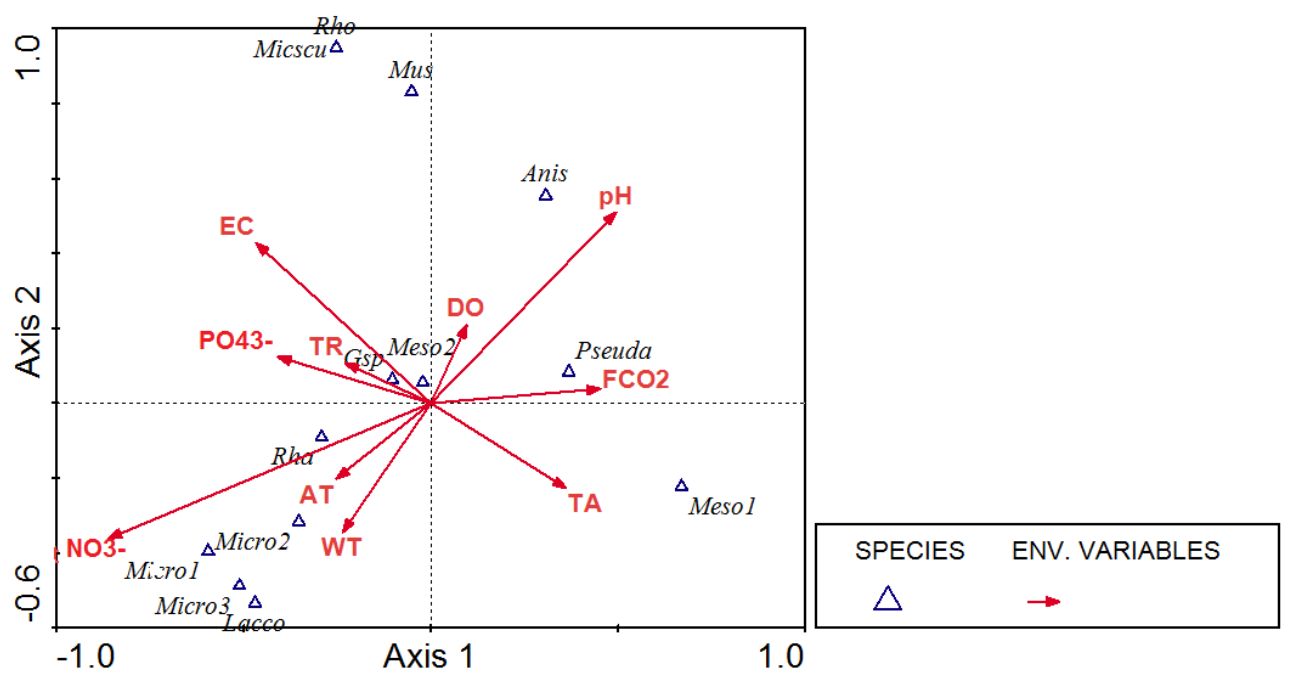

Figure 3

CCA biplot for taxa-environmental variables showing the relationship between the aquatic insect community and environmental variables in Radhamadhav akhra pond.

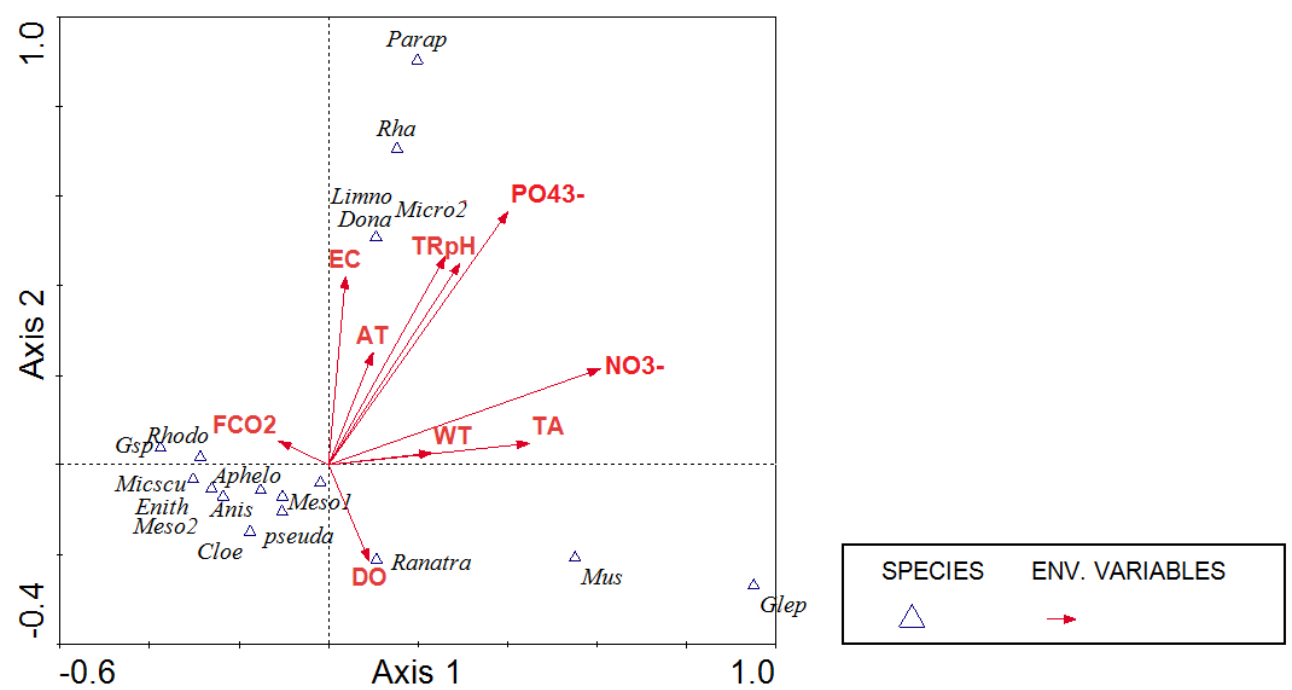

Figure 4

CCA biplot for taxa-environmental variables showing the relationship between the aquatic insect community and environmental variables in Mandir dighi pond.

with low $\mathrm{FCO}_{2}$ and increased DO. Ranatra varipes was found positively correlated with the increased DO while Donacia sp., Limnogonus nitidus, and Microvelia sp.1 were more associated with increased EC and AT. $\mathrm{FCO}_{2}$ was negatively correlated with $\mathrm{DO}$ and nitrate. CCA biplot revealed that most of the variables of water except $\mathrm{FCO}_{2}$ and $\mathrm{DO}$ were strongly positively correlated with each other and were grouped together in the positive side of both axis 1 and 2. This was also proved in the correlation matrix. Subsequently it was recorded that a large number of insect taxa were clubbed together in the negative side of axis 1 and 2 which confirmed that they were independent of all the variables of water (Table IX).

\section{CONCLUSIONS}

This study revealed that besides providing several ecosystem services these ponds with several microhabitats can serve as very good repositories of urban aquatic fauna. The governing 


\section{Table VII}

Summary statistics of CCA between aquatic insect taxa and environmental variables for first two axes in Radhamadhav akhra pond.

\begin{tabular}{|l|c|c|}
\cline { 2 - 3 } \multicolumn{1}{c|}{} & Axis 1 & Axis 2 \\
\hline Eigen values & 0.780 & 0.658 \\
\hline Taxa-environment correlation & 0.956 & 0.947 \\
\hline Cumulative percent variance of taxa data & 18.4 & 33.9 \\
\hline Cumulative percent variance of taxa-environment relation & 25.4 & 46.7 \\
\hline Sum of all Eigen values & \multicolumn{2}{|c|}{4.24} \\
\hline Sum of all canonical values & \multicolumn{2}{|c|}{3.077} \\
\hline Monte Carlo test of significance of all canonical axes; P-value & \multicolumn{2}{|c|}{0.0020} \\
\hline
\end{tabular}

\section{Table VIII}

Summary statistics of CCA between aquatic insect taxa and environmental variables for first two axes in Mandir dighi pond.

\begin{tabular}{|l|c|c|}
\cline { 2 - 3 } \multicolumn{1}{c|}{} & Axis 1 & Axis 2 \\
\hline Eigen values & 0.825 & 0.740 \\
\hline Taxa-environment correlation & 0.958 & 0.935 \\
\hline Cumulative percent variance of taxa data & 12.0 & 22.8 \\
\hline Cumulative percent variance of taxa-environment relation & 25.3 & 48 \\
\hline Sum of all Eigen values & 6.849 \\
\hline Sum of all canonical values & \multicolumn{2}{|c|}{3.257} \\
\hline Monte Carlo test of significance of all canonical axes ; $\boldsymbol{P}$-value & \multicolumn{2}{|c|}{0.0020} \\
\hline
\end{tabular}

\section{Table IX}

Taxa name along with its code used in CCA for Radhamadhav akhra pond and Mandir dighi pond.

\begin{tabular}{|l|c|c|c|}
\hline \multicolumn{2}{|c|}{ Pond 1 } & \multicolumn{2}{c|}{ Pond 2 } \\
\hline Species name & Code name & Species name & Code name \\
\hline Gerris sp. & Gsp & Gerris sp. & Gsp \\
\hline Micronecta haliploides & Micscu & Gerris lepcha & Glep \\
\hline Microvelia diluta & Micro1 & Limnogonus nitidus & Limno \\
\hline Microvelia sp.1 & Micro2 & Aphelocheirus sp. & Aphelo \\
\hline Microvelia sp. 2 & Micro3 & Paraplea frontalis & Parap \\
\hline Rhagovelia sp. & Rha & Micronecta haliploides & Micscu \\
\hline Mesovelia sp. & Meso1 & Microvelia sp.1 & Micro2 \\
\hline Mesovelia vittigera & Meso2 & Rhagovelia sp & Rha \\
\hline Anisops sp. & Anis & Mesovelia sp. & Meso1 \\
\hline Rhopalosiphum nymphaeae & Rho & Mesovelia vittigera & Meso2 \\
\hline Pseudagrion sp. & Pseuda & Anisops sp. & Anis \\
\hline Musca sp. & Mus & Enitheras sp. & Enith \\
\hline Laccobius sp. & Lacco & Ranatra varipes & Ranatra \\
\hline & & Rhodothemis sp. & Rhodo \\
\hline & & Pseudagrion sp. & pseuda \\
\hline & & Cloeon sp. & Cloe \\
\hline & & Musca sp. & Mus \\
\hline & & Donacia sp. & Dona \\
\hline
\end{tabular}

factors for pond 1 were found to be $\mathrm{NO}_{3}^{-}, \mathrm{EC}$ and $\mathrm{pH}$ while the governing factors of pond 2 were $\mathrm{PO}_{4}^{3-}$ and $\mathrm{NO}_{3}^{-}$. Although both the ponds are temple ponds used for religious purposes, pond 2 is highly used for domestic purposes also by the inhabitants of the area which will have a detrimental impact on the water quality and biodiversity of the pond in the long run. The temple authorities and management should come forward with protective measures to save the ponds from deterioration and conserve biodiversity. 


\section{ACKNOWLEDGEMENTS}

The authors would like to acknowledge the Head, Prof. Jayashree Rout, Ph.D, Department of Ecology and Environmental Science, Assam University, Silchar, Assam, India for providing laboratory facilities.

\section{REFERENCES}

Abellan P., Sanchez-Fernandez D., Velasco J. and Millan A., 2005. Assessing conservation priorities for insects: status of water beetles in southeast Spain. Biol. Conserv., 12, 79-90.

Adams L.W., 1994. Urban Wildlife Habitats: A Landscape Perspective, Mineapolis, MN, University of Minnesota Press.

Alberti M., Marzluff J., Shulenberger E., Bradley G., Ryan C. and ZumBrunnen C., 2003. Integrating humans into ecology: Opportunities and challenges for studying urban ecosystems. Bioscience, $53,1169-79$.

Allan J.D. and Flecker A.S., 1993. Biodiversity conservation in running waters. BioScience, 43, 32-43.

APHA, 2005. Standard methods for the Examination of Water and Wastewater, 21st edn., Washington, D.C. USA.

Bal A. and Basu R.C., 1994a. Insecta: Hemiptera: Mesovelidae, Hydrometridae, Veliidae and Gerridae. In: State fauna Series 3: Fauna of West Bengal. Part 5, Zoological Survey of India, Culcutta, 511-534.

Bal A. and Basu R.C., 1994b. Insecta: Hemiptera: Belostomatidae, Nepidae, Notonectidae and Pleidae. In: State fauna Series 3: Fauna of West Bengal. Part 5, Zoological Survey of India, Culcutta, 535-558.

Bhat M.M., Yazdani T., Narain K., Yunus M. and Shukla R.N., 2009. Water Quality Status of Some Urban Ponds of Lucknow, Uttar Pradesh. J. Wetlands Ecology, 2, 67-73.

Biggs J., Williams P., Whitfield M., Nicolet P. and Weatherby A., 2005. 15 years of pond assessment in Britain: results and lessons learned from the work of Pond Conservation. Aquat. Conserv. Mar. Freshw. Ecosyst., 15, 693-714.

Bouchard R.W., Jr., 2004. Guide to Aquatic Invertebrates of the Upper Midwest. Water Resources Center, University of Minnesota, St. Paul, MN, 208.

Braasch D. and Jacob U., 1976. Die Verwendung von Ephemeropteren (Insecta) der DDR als indicatoren fur die Wassergiitte. Entomologische Nachrichten, 20, 101-109.

Brabrand A.F., Faafeng B. and Nilssen J.P.M., 1990.Relative importance of phosphorus supply to phytoplankton production, fish excretion versus external loading. Canadian J. Fish. Aquat. Sci., 47, 364-372.

Brittain J.E., 1974. Studies on the lentic Ephemeroptera and Plecoptera of Southern Norway. Norsk Entomologisk Tidsskrift, 21, 135-151.

Brönmark C. and Hansson L.A., 2000. Chemical communication in aquatic systems: an introduction. Oikos, 88, 103-111.

Chessman B.C., 2003. New sensitivity grades for Australian river macroinvertebrates. Marine Freshw. Res., 54, 95-103.

Das K. and Gupta S., 2010. Aquatic Hemiptera Community of Agricultural Fields and Rain Pools in Cachar District, Assam, North East India. Assam University Journal of Science \& Technology: Biol. Sci., 5, 123-128.

Dudgeon D., 2003. The contribution of scientific information to the conservation and management of freshwater biodiversity in tropical Asia. Hydrobiologia, 500, 295-314.

Duncan J.R. and Lockwood J.L., 2000. Extinction in a field of bullets: a search for causes in the decline of the world's freshwater fishes. Biol. Conserv., 102, 97-105.

Engelmann H.D., 1978. Zur Dominanzklassifikazierung von Bodenarthropoden. Pedobilogia, 18, $378-380$.

Epler J.H., 2010. The Water Beetles of Florida- an identification manual for the families Chrysomelidae, Curculionidae, Dryopidae, Dytiscidae, Elmidae, Gyrinidae, Haliplidae, Helophoridae, Hydraenidae, Hydrochidae, Hydrophilidae, Noteridae, Psephenidae, Ptilodactylidae and Scirtidae. Florida Department of Environmental Protection, Tallahassee, FL. $399+$ iv p. 
Falkenmark M. and Folke C., 2003. Theme issue: Freshwater and welfare fragility: Syndromes, vulnerabilities and challenges, Royal Society's Philosophical Transactions B Biology, 358, 1440.

Fernando C.H. and Cheng L., 1974. A preliminary study on the fauna and distribution of aquatic Hemiptera in Malaya and Singapore. Federation Museums J., 19, 21-46.

Garcia de Jalon D. and Gonzalez del Tanago M., 1986. MetodosBiologicos para el Estudio de la Calidad de las Aguas. Aplicacion a la Cuenca del Duero, ICONA, Madrid, $241 \mathrm{p}$.

Gilbert O.L., 1989. The Ecology of Urban Habitats. Chapman \& Hall, New York, 369 p.

Gooderum J. and Tsyrlin E., 2002. The Waterbug book, A guide to the Freshwater Macro-invertebrates of Temperate Australia, CSIRO Publishing, Collingwood Vic.

Green A.J., El Hamzaoui M., El Agbani M.A. and Franchimont J., 2002. The conservation status of Moroccan wetlands with particular reference to waterbirds and to changes since 1978. Biol. Conserv., 104, 71-82.

Gupta S. and Narzary R., 2013. Aquatic insect community of lake, Phulbari anua of Cachar, Assam. J. Environ. Biol., 34, 591-597.

Hellawell J., 1986. Biological Indicators of Freshwater Pollution and Environmental Management. Elsevier Applied Science Publ, London and New York.

Hubbard M.D. and Peters W.L., 1978. Environmental requirements and pollution tolerance of Ephemeroptera.EPA 600-4-78-061 U.S. Environmental Protection Agency, Cincinnati, OH, VI.

Janieva I., 1979. Einigevertreter der Gattung Baetes (Ephemeroptera) als Limnosaprobe bioindikatoren. In: Pasternak K. and Sowa R. (eds.), Proceedings of the second International Conference on Ephemeroptera, Warsaw and Krakow: Panstwowe Wydawnictwo naudkowe, 139-143.

Kumar A., 1973a. Descriptions of the last instar larvae of odonata from the Dehra Dun Valley (India), with notes on biology I (Suborder: Zygoptera). Oriental Insects, 7, 23-61.

Kumar A., 1973b. Descriptions of the last instar larvae of Odonata from the Dehra Dun Valley (India), with notes on biology I I. (Suborder: Anisoptera). Oriental Insects, 7, 291-331.

Lansbury I., 1972. A revision of the genus Telmatotrephes Stal (Hemiptera - Heteroptera, Nepidae). Zoologica Scripta, 1, 271-286.

Lenat D.R., Smock L.A. and Penrose D.L., 1980. Use of benthic macroinvertebrates as Indicators of Environmental Quality. In: Douglass L.W. (ed.), Biological Monitoring for Environmental Effects, Lexington books, Toronto, 97-114.

Macan T. T and Maudsley R., 1968. The insects of the stony substratum of Windermere. Transaction of the Society for British Entomology, 18, 1-18.

McAbendroth L., Foggo A., Rundle S.D. and Bilton D.T., 2005. Unravelling nestedness and spatial pattern in pond assemblages. J. Anim. Ecology, 74, 41-49.

Menetrey N., Oertli B., Sartori M., Wagner A. and Lachavanne J.B., 2008. Eutrophication: are mayflies (Ephemeroptera) good indicators for ponds? Hydrobiologia, 597, 125-135.

Michael P., 1984. Ecological Methods for Field and Laboratory Investigation. Tata Mc. Graw-Hill publishing Company Ltd., New Delhi, $434 \mathrm{p}$.

Middleton J., 1994. Effects of urbanization on biodiversity in Canada. In: Biodiversity in Canada: A Science Assessment for Environment Canada. Environment Canada, Ottawa, 15-20.

Perez-Losada M., Jara C.G., Bond-Buckup G. and Crandall K.A., 2002. Conservation phylogenetics of Chilean freshwater crabs Aegla (Anomura, Aeglidae): assigning priorities for aquatic habitat protection. Biol. Conserv., 105, 345-353.

Purkayastha P. and Gupta S., 2012. Insect Diversity and Water Quality Parameters of Two Ponds of Chatla Wetland, Barak Valley, Assam. Curr. World Environ., 7, 243-250.

Purkayastha P. and Gupta S., 2013. Estimating ecosystem health of shallow water pond in lower Irongmara, Barak Valley, Assam, India, using ASPT, SPI and BMWP score. Int. Res. J. Biol. Sci., 2, $1-4$.

Rosenberg D.M. and Resh V.H., 1993. Freshwater biomonitoring and benthic invertebrates. Chapman and Hall publication, New York, $488 \mathrm{p}$.

Russev B.K., 1979. Die anpassunsfahigkeit der ephemeropteren and die Verunreiningung der Gewasser un die Moglichkeit ihrer ausnutzung als Limnosaprobe Bioindikatoren. In: Pasternak K. and Sowa R. (eds.), Proceedings of the second International Conference on Ephemeroptera, Warsaw and Krakow: Panstwowe Wydawnictwo Naudkowe, pp. 145-149. 
Schloesser D.W. and Nalepa T.F., 2002. Comparison of 5 benthic samplers to collect burrowing mayfly nymphs (Hexageniaspp: Ephemeroptera: Ephemeridae) in sediments of the Laurentian Great Lakes. J. N. Amer. Benthol. Soc., 21, 487-501.

Subramanian K.A. and Sivaramakrishnan K.G., 2007. Aquatic Insects for Biomonitoring Freshwater Ecosystems - A Methodology Manual. Asoka Trust for Research in Ecology and Environment (ATREE), Bangalore, India, $31 \mathrm{p}$.

Takhelmayum K. and Gupta S., 2011. Distribution of aquatic insects in phumdis (floating island) of Loktak Lake, Manipur, northeastern India. J. Threatened Taxa, 3, 1856-1861.

Thorpe W.H., 1950. Plastron respiration in aquatic insects. Biological Reviews of the Cambridge Philosophical Society, 25, 344-390.

Thorpe W.H. and Crisp D.J., 1947. Studies on plastron respiration. I. The biology of Aphelocheirus (Hemiptera, Aphelocheiridae) and the mechanism of plastron retension. J. Exp. Biol., 24, 227-270.

Turkmen G. and Kazanci N., 2010. Applications of various biodiversity indices to benthic macroinvertebrate assemblages in streams of a national park in Turkey. Rev. Hydrobiol., 3, 111-125.

United Nations, 1999. The State of World Population 1999-1996 Billion: A Time for Choices. United Nations Population Fund, New York.

Wackernagel M. and Rees W., 1996. Our Ecological Footprint: Reducing Human Impact on the Earth. The New Catalyst Bioregional Series, New Society Publishers, $160 \mathrm{p}$.

Wallace J.B. and Webster J.R., 1996. The role of macro-invertebrates in stream ecosystem function. Annual Rev. Entomol., 41, 115-139.

Wells R.M.G., Hudson M.J.Q. and Brittain T., 1981. Function of the haemoglobin and the gas bubble in the backswimmer Anisops assimilis (Hemiptera, Notonectidae). J. Comparative Physiology, 142, 515-522.

Westfall M.J. and Tennessen K.J., 1996. Odonata. In: Merrit, R. and Cummins., (eds), An Introduction to the Aquatic Insects of North America, 3rd edn., Kendall-Hunt Publishing Co., Dubuque, IA, 164-211.

Williams P., Whitfield M., Biggs J., Bray S., Fox G., Nicolet P. and Sear D., 2004. Comparative biodiversity of rivers, streams, ditches and ponds in an agricultural landscape. Biol. Conserv., 115, 329-341. 